\title{
PROACTIVE PLANNING OF PROJECT TEAM MEMBERS' COMPETENCES
}

\author{
Eryk SZWARC*, Jarosław WIKAREK** \\ *Koszalin University of Technology, Faculty of Electronics and Computer Science, Koszalin, POLAND \\ e-mail: eryk.szwarc@tu.koszalin.pl \\ ** Kielce University of Technology, Institute of Management and Control Systems, Kielce, POLAND \\ e-mail: j.wikarek@tu.kielce.pl
}

\begin{abstract}
Among the many factors that cause project delays or cancellations are disruptions, that is, unforeseen events occurring during the implementation of a project, which postpone or interrupt the performance of project activities. Examples of disruptions include employee absenteeism, addition of new activities, and others. One way to deal with this type of events is to predict potential disruptions and prepare redundant resources to be used should a disruption occur (proactive approach). The focus of the present paper are human resources, in particular redundant project team competence frameworks, which allow to continue work on a project in the event of a disruption. Previous studies on planning competence frameworks regard insensitivity (robustness) to one type of disruption, caused by employee absenteeism (an absence of one, two, or three employees). The goal of this article is to present a proactive procedure that allows to seek competence frameworks robust to two types of disruptions: absence of one employee and addition of new activities not included in the project plan. Examples are provided to illustrate how the proposed approach can be used in practice.
\end{abstract}

Keywords: project team, proactive planning, competences, robustness, disruptions.

JEL Classification: O15, C63, C61, O21, J24.

\section{$1 \quad$ Introduction ${ }^{1}$}

The transformations that are taking place in the economy and organizational environments today require the implementation of projects (Oberlander, 2000; Mingus, 2002). Many authors (Marques, et al., 2011; Sitek and Ziółkowski, 2014; Vaagen, et al., 2017) emphasize that decision making regarding all project resources (financial, material, and human) plays a key role in project management. It is recognized that the main resource that determines whether a project will be completed on time are people (the project team) (Drucker, 1993). That is why, proper selection of project team members already at the stage of planning project resources is so important with regard to both an organization's full-time employees and personnel from external companies or outsourced personnel (Armstrong and Taylor, 2002; Pocztowski and Miś, 2000). Candidates for team members can be assessed on many dimensions: knowledge, skills, experience, qualifications, personality, physical fitness, and so on (Antczak and Sypniewska, 2017; Grabara, et al.,
2016). Some of these dimensions compose competences, which are the key capital of companies (including those that implement projects) and the principal determinant of their success (Kupczyk, 2014). Many authors report a positive correlation between employee competences and a company's performance (Becker and Huselid, 2006; Gangani, et al., 2006; Teodorescu, 2006; Appelbaum, et al., 2000; Kalmi and Kauhanen, 2008).

It is worth noting that now virtually every organization operates in a changing and uncertain environment, increasingly dominated by technological and organizational innovations, growing competition, employee turnover, and so on (Bombiak, 2017). This means that unforeseen events, called disruptions, can occur during the implementation of projects (Bocewicz, et al., 2016; Ingels and Maenhout, 2019; Klimek and Łebkowski, 2011), leading to non-completion of project activities or, at best, a delay in carrying them out. As a consequence, in most cases, staffing decisions regarding the appointment of pro-

\footnotetext{
${ }^{1}$ The work was supported by the National Science Centre, Poland,under research project no: 2019/33/N/HS4/00379.
} 
ject teams are subject to uncertainty related to the temporary unavailability of resources (e.g., absence of employees), changes in the start times/durations of activities (resulting from delays in the completion of previous activities), the addition of new activities to the ongoing project (as a result of changes in customer requirements or introduction of new/amendment of existing legislative acts), and so on.

The problem considered in this study can be formulated as follows: we assume that given is a project (consisting of a finite number of activities) that is implemented according to a specific schedule (it is known which activity begins and ends in which unit of time). The time horizon for completing the project is known. It is assumed that the competences required to perform each activity are known. A team of employees is allocated to the execution of project activities. It is known which employee has what competences (what activities they can perform). It is assumed that a given activity can be performed by only one competent employee. Conversely, one employee can perform many activities, but must not perform more than one activity at a time. The personnel assignment that takes account of the above assumptions is known. This means that the times when an employee is busy performing a task are also known. During the implementation of the project, no changes in activity start/end times or the personnel performing the activities are allowed.

Assuming that during the implementation of the project, there may occur two types of disruptions: an absence of any one of the employees and an addition of one new activity with known duration, start/end times, and competences required for its execution, the following question needs to be answered: Will the project be completed within the given time horizon if it is disrupted in this way? In other words, in the case of an absence, is it possible to replace the absent employee with another (available, free and competent) employee, and is it also possible to assign the new activity to an available, free and competent employee? If not, which employee should acquire what competences for the project to accommodate such a situation?

In this context, the concept of proactive planning of a project team proposed in this study boils down to appointing teams with redundant competences.
These competencies should be chosen so that, when the anticipated disruptions do occur, the project can be completed within the given time horizon. Competence frameworks that guarantee the possibility of finishing a project on time are referred to as being robust to a specific set of disruptions. Put another way, a robust competence framework is one that guarantees timely implementation of the assumed plan (project) despite the occurrence of a specific type of disruptions.

As a consequence, the planning of competence frameworks that can guarantee timely implementation of a project comes down to seeking (synthesizing) alternative competence frameworks that are robust to the given (a priori known) set of disruptions. In general, to obtain a robust competence framework, a company may have to upskill/retrain their personnel and/or hire additional staff.

Because the problem under consideration is NP-hard (Szwarc, et al., 2019b), it was solved using constraint programming (CP) (Nielsen, et al., 2014; Sitek 2014), a technique that helps reduce the calculation time, compared to full review methods (such as the branchand-bound method). This technique requires that the problem be represented using a declarative model. In this paper, we propose a declarative model of planning competence frameworks robust to the selected types of disruptions, which can be directly implemented in commercially available constraint programming environments, such as ECLiPSe, IBM iLog CPLEX, Gurobi, and so on.

Section 2 presents a review of the literature on competences, qualifications, balancing of competences, and competence frameworks. Section 3 deals with the issue of planning personnel competence frameworks under uncertainty. It defines concepts such as disruption and robustness of a competence framework to disruptions. Section 4 presents the model of the problem under discussion. The paper ends with conclusions and an indication of directions for future research.

\section{$2 \quad$ Literature review}

In order to assemble a competent project team, it is necessary to identify two sets of competences: those that are required and those that the employees already 
have. Maintaining the two sets in balance is called balancing of competences (Kuruba, 2019). When the result of balancing is negative, that is, when the competences are insufficient or excessive, project team members have to supplement their qualifications (the competence gaps have to be filled in) or be retrained (Antosz, 2018). It should be noted here that the terms competence and qualification are often used interchangeably. However, many examples from the literature of the subject (Cheng, et al., 2003; Teodorescu, 2006; Kupczyk and Stor, 2015) show that they are not synonymous.

\subsection{Competences and qualifications}

There are two different trends in thinking about competences: the American approach (used in the USA) and the British approach (used in Europe). In the US, job/work analysis is person-oriented (e.g., behavioral event interviews are used). The goal is to identify those features that distinguish individuals with above average performance/capabilities from others. Competences include skills, personal traits and behavior (Cheng, et al., 2003; Kupczyk and Stor, 2015). Therefore, Americans use the concept of competency. In Great Britain, on the other hand, task-oriented job/work analysis techniques are used, which are based on functional analysis, the purpose of which is to identify the necessary roles, activities and responsibilities related to a job rather than the abilities of the people who do it (Cheng, et al., 2003; Kupczyk and Stor, 2015). Consequently, the British tend to use the term competences or qualifications (Stor, 2014).
In the French vocational training system, the term compétence ("competence") was originally used to describe a person's ability to perform a task/activity. Over time, the term has started to be used in general education to define a person's potential /capability to act effectively in a given situation (Romainville, 1996). A similar definition of competence is given by another French author (Perrenoud, 1997), who claims that competence is a (chiefly) knowledgebased "ability to act effectively in many specific situations".

Yet another distinction between competences and qualifications is made by Kupczyk and Stor (Kupczyk and Stor, 2017) in the context of the Polish language. According to those authoresses, "qualifications make an employee capable of fulfilling their duties in a given position, while competences determine whether they perform their work in this position in the expected manner". In other words, qualifications are associated with a person's formally documented knowledge, skills, and psychological features.

Competences, on the other hand, "are determined by comparing an employee's current performance or achievements with the performance or achievements specified in performance standards (models) developed in accordance with the qualification standards applied in a given occupational environment".

The definitions cited above show that the line between the two concepts can be drawn in many different ways. Sometimes the difference between them is negligible. Most authors consider competences to involve more than qualifications, sometimes treating the latter as a component of the former (Table 1).

Table 1. Comparison of the terms qualifications and competences

(Source: Compiled by the authors)

\begin{tabular}{|c|c|}
\hline Qualification & Competence \\
\hline $\begin{array}{l}\text { a formal recognition of education or skills } \\
\text { (e.g. a diploma, a certificate) }\end{array}$ & $\begin{array}{l}\text { the right to perform particular activities / } \\
\text { make decisions }\end{array}$ \\
\hline $\begin{array}{l}\text { a level of knowledge, skills and experience } \\
\text { that allow a person to perform particular activities }\end{array}$ & $\begin{array}{l}\text { a set of necessary roles, activities and responsibilities } \\
\text { related to a person's job }\end{array}$ \\
\hline describes actions that a person can perform & describes the way of performing actions \\
\hline is unrelated to attitudes, personality, behaviour, etc. & is related to attitudes, personality and behaviour \\
\hline
\end{tabular}


Because the concept of competence has a broader meaning, it is this concept that is the focus of the present study. Competences are understood here as all those features that allow a person to achieve the goals set. Qualifications, on the other hand, are viewed as a component of competence, a formal expression (diplomas/certificates) of an individual's ability to perform specific activities.

In other words, we adopt here the definition espoused by the United Nations Industrial Development Organization (Sampson and Fytros, 2008), according to which, competence is a set of knowledge, features and skills that a person needs to accomplish an activity within a specific job.

\subsection{Balance of competences}

It is obvious that the level of competences possessed by an employee should be at least equal to the level of required competences (Fig. 1a). If this is not the case (if the existing competences are insufficient) (Fig. 1b), efforts are made to balance the competences possessed by the employees with those required by the project (Fig. 2).
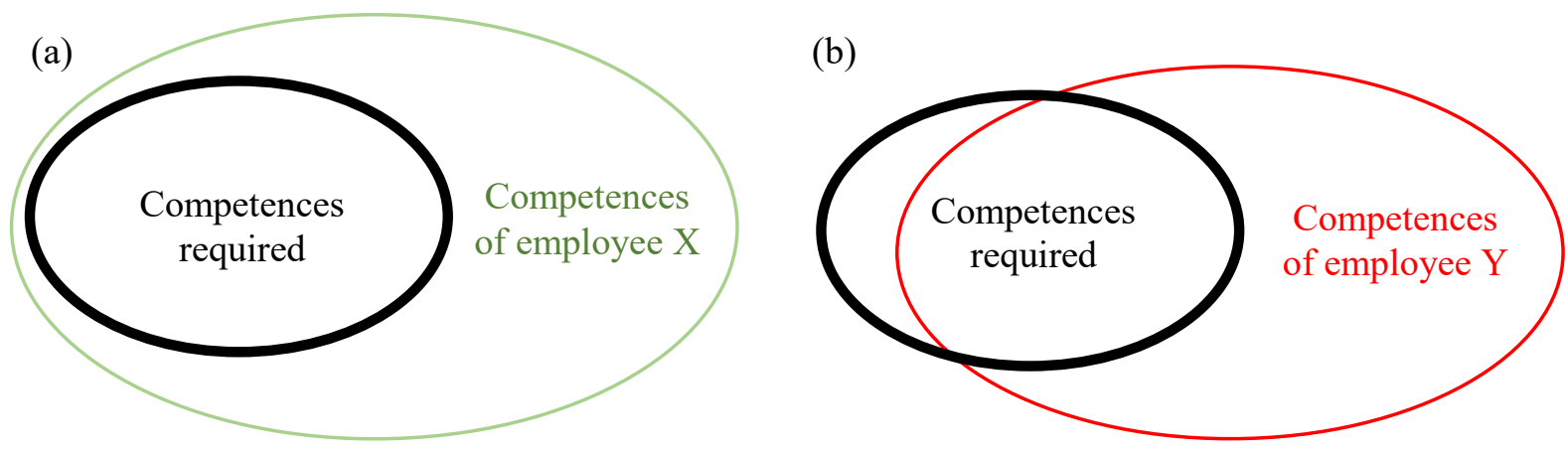

Figure 1. Illustration of sufficient (a), insufficient (b) competences

(Source: Prepared by the authors)

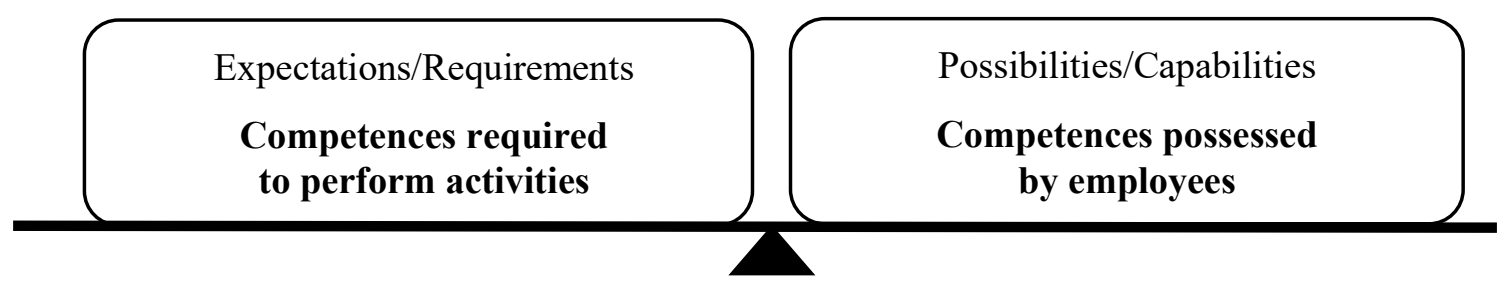

Figure 2. Balancing of competences (Source: Prepared by the authors)

In practice, it is often necessary to balance the competences of many employees (employee teams) with competences required to carry out many activities. The question is how the competences of many people can be represented?

A frequently used method of representation is the competence matrix (Kuruba, 2019), in which the rows usually represent employees and the columns list their competences. In the matrix, values/symbols mark the current level of each specific competence for each employee.

An example of a competence matrix in which competences are rated on a five-point scale is shown in Fig. 3. 


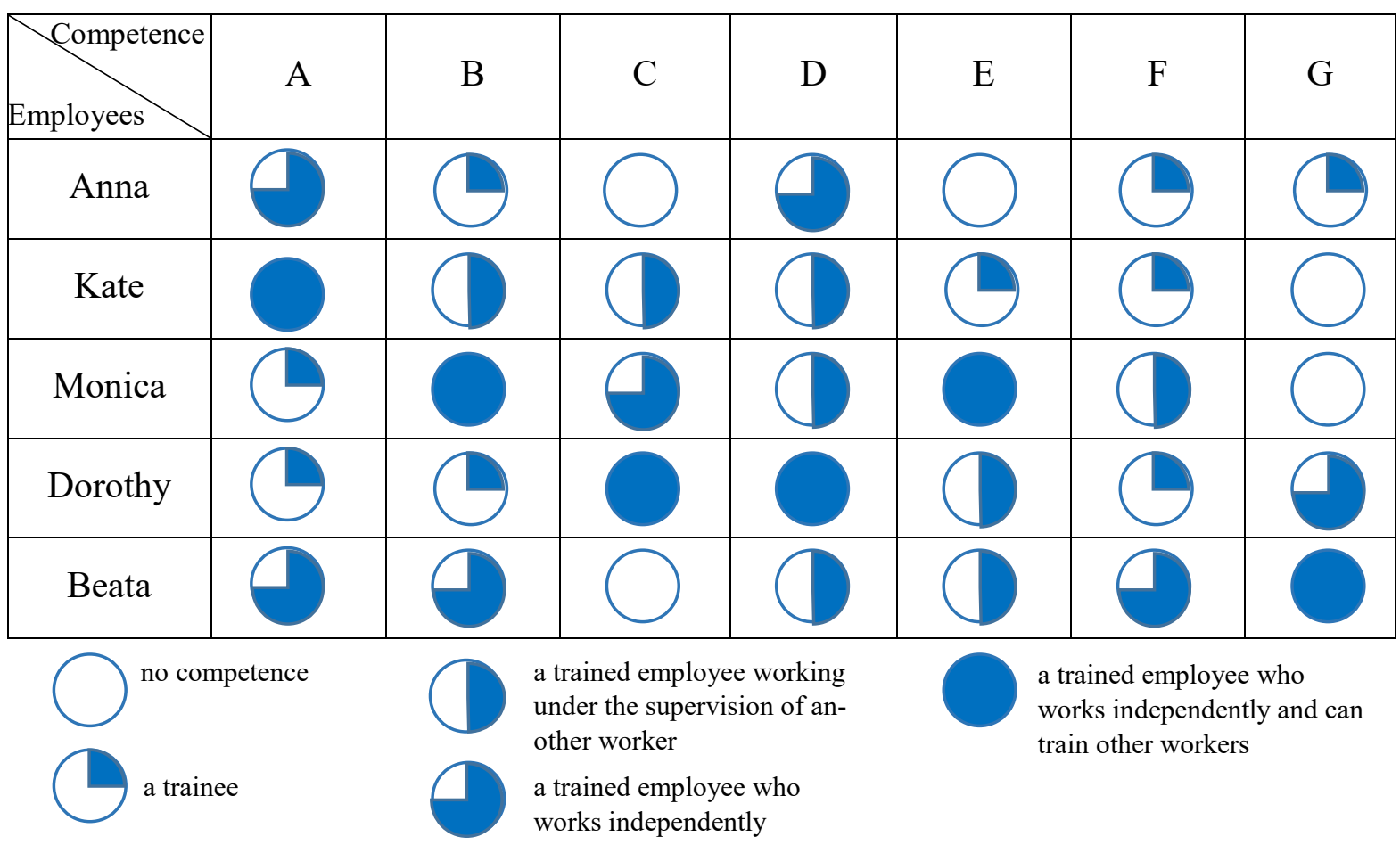

Figure 3. An example of a competence matrix (Source: infor.pl, a translation from Polish)

An employee's competence level is represented as a Harvey ball, with each quadrant depicting a growing level of competence. One shaded quadrant means that the employee is a trainee, two shaded quadrants indicate that they have completed their training and can perform activities under the supervision of an experienced colleague, three shaded quadrants mean that they can perform activities on their own, and four shaded quadrants indicate that the employee is not only an independent worker but can also train others. An unshaded Harvey ball represents a lack of competence in the particular area.

For example, employee Anna from the matrix in Fig. 3 does not have two competences $(\mathrm{C}, \mathrm{E})$, is still training to acquire three other competences $(\mathrm{B}, \mathrm{F}, \mathrm{G})$, and has two competences that allow her to do the tasks involved on her own (A, D).

The multi-level form of the competence matrix can be used as an element supporting the decision-maker in assessing whether a given employee is capable (has sufficient competencies) to perform a specific task. For example, if task $\mathrm{X}$ requires competence $\mathrm{A}$, then on the basis of the matrix in Fig. 3 employees with a given (minimal) level can be selected. Therefore, it is necessary to set a limit for which the required level of competence will be determined.

For example, assume that for all competencies, level named "a trained employee who works independently" is required. In this context, it should be noted that each multi-level representation of competence matrix boils down to a binary, as is shown in Table 2 (the value "1" means having a specific competence at the required level, the value " 0 " having an insufficient level of competence).

The elements of the matrix make up an organized whole, which can be called a framework. Accordingly, the competences of employee teams will be henceforth referred to as a binary competence framework. 
Table 2. An example of a binary competence framework

(Source: Authors' own study)

\begin{tabular}{|c|c|c|c|c|c|c|c|}
\hline Employees & A & B & C & D & E & F & G \\
\hline Anna & 1 & 0 & 0 & 1 & 0 & 0 & 0 \\
\hline Kate & 1 & 0 & 0 & 0 & 0 & 0 & 0 \\
\hline Monica & 0 & 1 & 1 & 0 & 1 & 0 & 0 \\
\hline Dorothy & 0 & 0 & 1 & 1 & 0 & 0 & 1 \\
\hline Beata & 1 & 1 & 0 & 0 & 0 & 1 & 1 \\
\hline
\end{tabular}

The methods of balancing competences described in the literature do not take into account phenomena (disruptions), such as absenteeism, added activities, delays during the execution of activities, and so on. The next section is devoted to the analysis of existing methods of planning competence frameworks under uncertainty conditions.

\section{The non-determinism of project implementation}

Unforeseen events occurring during the implementation of a project may concern its different aspect/elements (Zhu, et al., 2005), such as:

- project activity networks, for example:

- the addition of new activities,

- the emergence of new constraints on the order in which activities are performed

- activities, for example:

- changes in the duration of activities during the execution of the project schedule (e.g., shortening of the completion times of specific activities),

- delays in activity start times (caused by events such as late delivery of materials by suppliers),

- changes in the demand for resources required for the execution of particular activities,

- resources, for example:

- temporary unavailability of a resource (e.g., machine failure, accident, illness),

- permanent reduction in the availability of a resource (e.g., employee turnover),
- deadlines, for example:

- a change in the project deadline,

- changes in project milestone dates.

The time of the occurrence of the particular disruption may be known (an anticipated disruption) or not (an unanticipated disruption). Similarly, the probability of occurrence of a disruption at a particular time in the project may be known. Because of the dynamics of changes in a company's environment mentioned in the Introduction, decision-makers usually cannot predict the probable, not to mention the accurate time at which a disruption may occur, for example, which employee will be absent in what time period, which materials will be delivered with what delay, and so on. In this context, the crucial question is how disruptions may affect a project and what, if anything, can be done to counteract them?

\subsection{Reactive approach}

The most common reaction to disruptions caused by events such as employee absences is to look for such modifications of the project schedule (socalled re-scheduling) that will allow the project to be continued (reactive approach). Whether or not such changes can be made depends, among other things, on the competences of available employees. In a special case, it may turn out that the competences of the remaining staff are insufficient to allow the company to introduce appropriate changes in their assignment to activities in the event of a disruption (i.e., changes that will allow to continue project activities). This situation is illustrated by the example below. 


\section{Example}

Consider a project consisting of 10 activities $\mathrm{Z}_{1}-\mathrm{Z}_{10}$ and employees $\mathrm{P}_{1}-\mathrm{P}_{8}$ assigned to these activities as shown in Fig. 4.

The personnel assignment shown in Fig. 4 is feasible when:

- the employees have competences A-F to perform the particular project activities (Table 3) - e.g., competence $\mathrm{A}$ is required to perform activity $\mathrm{Z}_{1}$, competence $\mathrm{B}$ is required to perform activity $\mathrm{Z}_{2}$, and so on,

- the project team has a competence framework as in Table 4, in which " 1 " means that a specific employee has the competence to perform a given activity, and " 0 " means an employee does not have such competence.

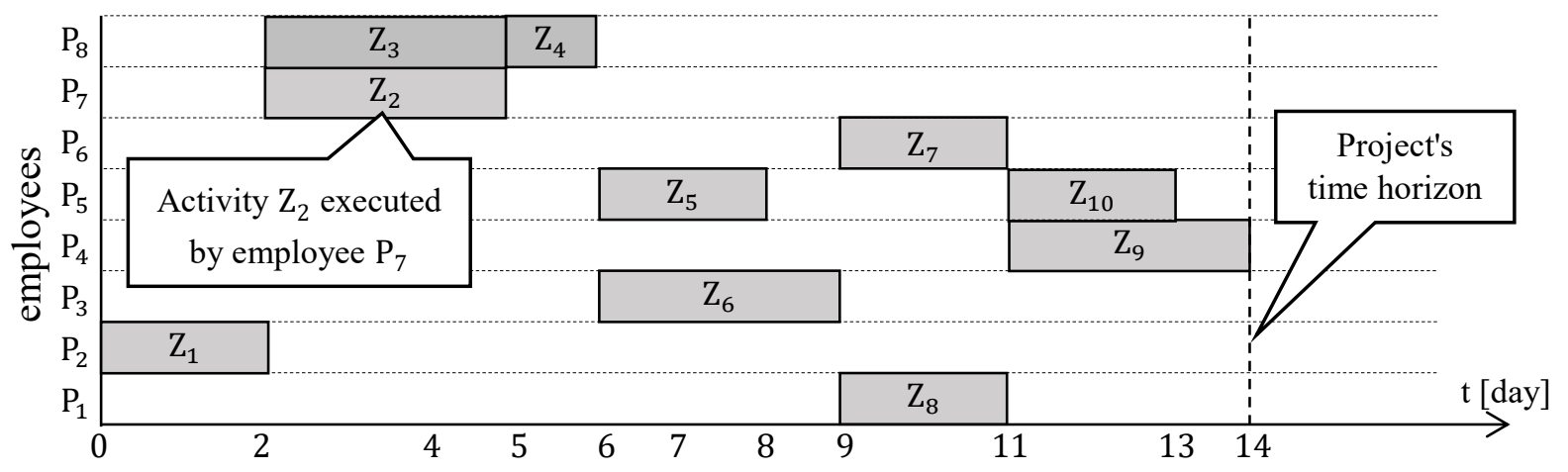

Figure 4. Employees assignment (Source: Authors' own study)

Table 3. Required competences (Source: Authors' own study)

\begin{tabular}{|c|c|c|c|c|c|c|c|c|c|c|}
\hline Activity & $\mathrm{Z}_{1}$ & $\mathrm{Z}_{2}$ & $\mathrm{Z}_{3}$ & $\mathrm{Z}_{4}$ & $\mathrm{Z}_{5}$ & $\mathrm{Z}_{6}$ & $\mathrm{Z}_{7}$ & $\mathrm{Z}_{8}$ & $\mathrm{Z}_{9}$ & $\mathrm{Z}_{10}$ \\
\hline Required competences & $\mathrm{A}$ & $\mathrm{B}$ & $\mathrm{D}$ & $\mathrm{F}$ & $\mathrm{E}$ & $\mathrm{C}$ & $\mathrm{A}$ & $\mathrm{C}$ & $\mathrm{F}$ & $\mathrm{E}$ \\
\hline
\end{tabular}

Table 4. Competence framework with activity $\mathrm{Z}_{11}$ added (Source: Authors' own study)

\begin{tabular}{|c|c|c|c|c|c|c|c|c|c|c|c|}
\hline $\begin{array}{l}\text { Employee } \mathrm{P}_{\mathrm{i}} \\
\text { (possessed competences) }\end{array}$ & $\mathrm{Z}_{1}$ & $\mathrm{Z}_{2}$ & $\mathrm{Z}_{3}$ & $\mathrm{Z}_{4}$ & $\mathrm{Z}_{5}$ & $\mathrm{Z}_{6}$ & $\mathrm{Z}_{7}$ & $\mathrm{Z}_{8}$ & $\mathrm{Z}_{9}$ & $\mathrm{Z}_{10}$ & $\mathrm{Z}_{11}$ \\
\hline $\mathrm{P}_{1}(\mathrm{~B}, \mathrm{C})$ & 0 & 1 & 0 & 0 & 0 & 1 & 0 & 1 & 0 & 0 & 0 \\
\hline $\mathrm{P}_{2}(\mathrm{~A}, \mathrm{D})$ & 1 & 0 & 1 & 0 & 0 & 0 & 1 & 0 & 0 & 0 & 0 \\
\hline $\mathrm{P}_{3}(\mathrm{C})$ & 0 & 0 & 0 & 0 & 0 & 1 & 0 & 1 & 0 & 0 & 0 \\
\hline $\mathrm{P}_{4}(\mathrm{~F})$ & 0 & 0 & 0 & 1 & 0 & 0 & 0 & 0 & 1 & 0 & 1 \\
\hline $\mathrm{P}_{5}(\mathrm{E})$ & 0 & 0 & 0 & 0 & 1 & 0 & 0 & 0 & 0 & 1 & 0 \\
\hline $\mathrm{P}_{6}(\mathrm{~A}, \mathrm{E})$ & 1 & 0 & 0 & 0 & 1 & 0 & 1 & 0 & 0 & 1 & 0 \\
\hline $\mathrm{P}_{7}(\mathrm{~B}, \mathrm{C})$ & 0 & 1 & 0 & 0 & 0 & 1 & 0 & 1 & 0 & 0 & 0 \\
\hline $\mathrm{P}_{8}(\mathrm{~B}, \mathrm{D}, \mathrm{F})$ & 0 & 1 & 1 & 1 & 0 & 0 & 0 & 0 & 1 & 0 & 1 \\
\hline
\end{tabular}


Consider a situation in which the project in question is disrupted by two events occurring simultaneously: an absence of one of the employees and the addition of a new (unplanned for) activity $Z_{11}$ that starts in the 5 th time unit, is performed over the span of 3 time units, and requires competence F (Fig. 5).

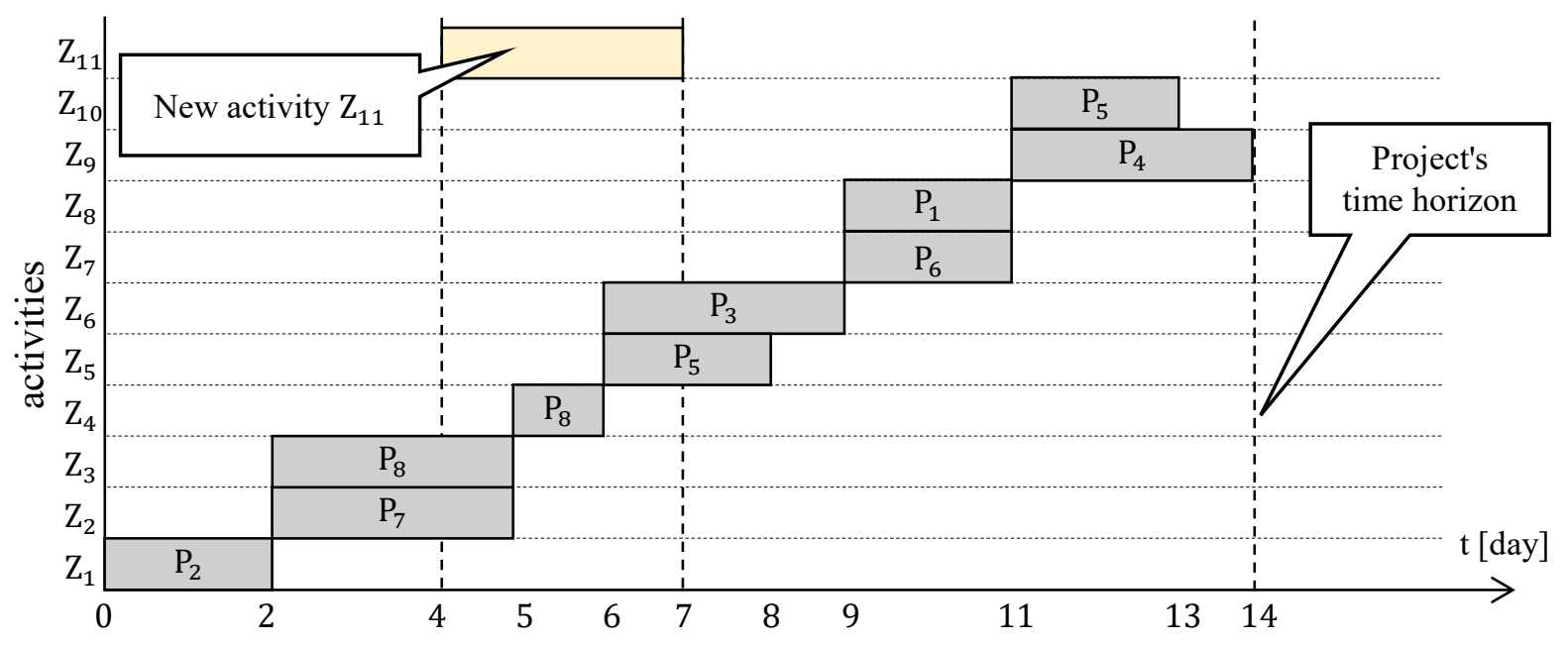

Figure 5. Project schedule with a new activity $\mathrm{Z}_{11}$

(Source: Authors' own study)

An activity may be added to an ongoing project as a result of changes in customer requirements, introduction of new or amendment of existing legislative acts, and so on. Let's consider an example of an IT project aimed at producing made-to-order software. During the implementation of the project, the customer decides that the software should incorporate a functionality that was not included in the original project plan. This modification forces the project contractor to incorporate additional activities $\mathrm{Z}_{11}$ into the project schedule. The decision maker (project manager) has to consider the following question: is it possible, given the company's competence framework, to find a substitute who is competent to perform $\mathrm{Z}_{11}$ and is available during the time allotted for the execution of $\mathrm{Z}_{11}$ whenever one of the employees is absent?

The competence framework presented in Table 4 shows that the new activity $\mathrm{Z}_{11}$ can be executed by employees $\mathrm{P}_{4}$ or $\mathrm{P}_{8}$ (the column marked in blue). Fig. 5 clearly shows that when one of these employees is absent (in the present example, it is employee $\mathrm{P}_{4}$ ), the introduction of the new activity will jeopardise timely implementation of the project. For instance, when $\mathrm{P}_{4}$ is absent, the new activity $\mathrm{Z}_{11}$ can only be performed by $\mathrm{P}_{8}$, who is assigned to the execution of $Z_{3}$ and $Z_{4}$. This means that the existing competence framework does not allow to find a replacement who is competent to perform $\mathrm{Z}_{11}$ and is available at the time when $\mathrm{Z}_{11}$ is scheduled in all cases of an absence of a single employee. What a decision-maker can do in this situation is to:

- make changes to the existing schedule by postponing/delaying activity deadlines,

- train team members in the competences required to carry out activity $\mathrm{Z}_{11}$,

- hire additional staff with the competences required to perform activity $\mathrm{Z}_{11}$.

The first solution usually results in untimely completion of the project (and financial losses due to the failure to meet the agreed deadline). The second solution requires time, which is lacking when the disruption occurs. The third may cause an unacceptable increase in project implementation costs.

\subsection{Proactive approach}

In the context of the problem discussed, the proposed proactive approach boils down to appointing (planning) employee teams with redundant competence frameworks. In other words, variants of redundant competence frameworks are sought, which ensure that the project is completed within the given time horizon 
despite the disruptions. Such competence frameworks are referred to as being robust to a specific set of disruptions.

The robustness of a competence framework is treated as a parameter dependent on the type of disruption, which can be assessed by various measures. For example, the robustness of a competence framework can be expressed as:

- a measure of robustness to cases of an absence of one employee: the number of absences for which there exists an activity assignment that guarantees the completion of orders relative to all possible cases of absenteeism,

- a measure of robustness to an employee's loss of qualifications (competences): the number of cases of lost qualifications for which there exists an activity assignment that guarantees timely completion of orders relative to all possible cases of loss of qualifications,

- a measure of robustness to changes in the structure of activities (changes in the number of activities, technological routes, etc.): the number of changes in the activity structure for which there exists an activity assignment that guarantees the completion of orders, relative to all possible cases of changes in the structure of activities,

\section{- and so on.}

Loss of competence is understood as the loss of opportunities to practice a profession / tasks, for example, a qualification certificate to perform the work of a professional driver, supervision rights for power equipment, and so on.

The planning of robust competence frameworks basically consists in looking for (synthesizing) alternative competence frameworks that are robust to the given (a priori known) set of disruptions. In general, this process may involve training/supplementary training of a company's personnel and/or hiring additional staff. Usually, training is the solution of choice.

If a company decides to train its existing personnel, the decision must be made regarding which employee should acquire what competence to make the framework in Table 4 robust to the type of disruption being considered.
Previous research (Szwarc, et al., 2019a, 2019b) shows that because of the computational complexity of the discussed problem $\left(\mathrm{f}(\mathrm{n}, \mathrm{m})=\mathrm{O}\left(2^{\mathrm{m} \cdot \mathrm{n}}\right)\right.$, where: $\mathrm{m}$ - number of employees, $\mathrm{n}$ - number of activities), in special cases, all variants of competence frameworks (in the example under consideration it is $2^{88}$ variants) have to be checked to obtain a solution. The analysis of such a large number of variants is time-consuming and, therefore, excludes the use of full review methods (such as the branch-and-bound method). To reduce calculation time, it is necessary to use time-efficient techniques that allow to search large data structures. In this study, we used a/the constraint programming (CP) technique (Nielsen, et al., 2014), which requires that a problem under consideration be represented as a declarative model. In contrast to procedural (imperative) modelling, the declarative approach allows to formulate models taking into account the specific needs and requirements of a given version of a problem.

In previous studies (Szwarc, et al., 2019a, 2019b; Bocewicz, et al., 2020), we developed a model of the synthesis of disruption-robust competence frameworks. That model was limited to situations in which there was just one type of disruption: employee absenteeism (an absence of one, two, or three employees). In this study, we present a declarative model that accommodates two types of disruption (an absence of one employee and an addition of a new activity).

\section{$4 \quad$ A declarative model of planning robust competence frameworks}

The model proposed in this study allows to find competence frameworks robust to disruptions caused by an absence of one employee and an addition of one new activity. This model assumes that: the project schedule (activity start times and activity duration) is known, an activity is performed by one employee only, it is known which employee can perform which activities (a binary competence framework), the allocation of employees to activities is known, each employee can acquire a new competence, and no changes in the start and end times of activities or the personnel performing the activities are allowed. 
Sets:

$Z_{i}$ - set of activities indexed by $i=1, \ldots, n$; the last activity $Z_{\mathrm{n}}$ in set $\mathrm{Z}$ is an added activity (a disruption),

$\mathrm{P}_{\mathrm{k}}$ - set of employees indexed by $\mathrm{k}=1, \ldots, \mathrm{m}$.

Parameters:

$l_{i}$ - duration of the $i$-th activity $Z_{i}$ (in days),

$\mathrm{y}_{\mathrm{i}}$ - start time of activity $\mathrm{Z}_{\mathrm{i}}$, (for activity $\mathrm{Z}_{\mathrm{n}}$, the start time is expressed as interval $y_{i}=[a, b]$ ),

$\mathrm{s}_{\mathrm{k}}^{\mathrm{j}}$ - minimum number of working time limit (lower time limit) of the k-th employee $\left(s_{k} \in \mathbb{N}\right)$ when the $\mathrm{j}$-th employee is absent,

$\mathrm{z}_{\mathrm{k}}^{\mathrm{j}}$ - maximum number of working time limit (upper time limit) of the k-th employee $\left(\mathrm{z}_{\mathrm{k}} \in \mathbb{N}\right)$ when the $\mathrm{j}$-th employee is absent,

$\mathrm{R}^{*}$ - expected robustness of a competence framework, $\mathrm{R}^{*} \in[0,1]$,

LP- the number of scenarios for which competence framework is robust to an employee's single absence.

Minimum of working time limit in practice means the well-known nominal working time (for example, 40 hours in a five day working week). Maximum of working time limit is the overtime limit (for example, 10 hours in a five day working week).

Decision variables:

$\mathrm{G}$ - a competence framework defined as $\mathrm{G}=$ $\left(\mathrm{g}_{\mathrm{k}, \mathrm{i}} \mid \mathrm{k}=1 \ldots \mathrm{m} ; \mathrm{i}=1 \ldots \mathrm{n}\right)$, where $\mathrm{g}_{\mathrm{k}, \mathrm{i}}$ stands for employees' competences to perform activities; $\mathrm{g}_{\mathrm{k}, \mathrm{i}} \in\{0,1\}, \mathrm{g}_{\mathrm{k}, \mathrm{i}}=0$ means that the k-th employee has no competences to perform the ith activity, and $g_{k, i}=1$ means that the k-th employee has the competences to perform the i-th activity

$\mathrm{R}$ - a measure of the robustness of competence framework $\mathrm{G}$ to the absence of one employee and ordering a new activity $\left(\mathrm{Z}_{\mathrm{n}}\right): \mathrm{R} \in[0,1] . \mathrm{R}=0-$ stands for lack of robustness, that is, each absence results in unassigned activities; $\mathrm{R}=1-$ stands for full robustness, that is, regardless of which employee is absent, all activities (with activity $Z_{n}$ ) are assigned to the available staff.
For example: $\mathrm{R}=0.25$ means that the competence framework ensures allocation of activities in one-quarter of the possible cases of absence of one employee; $\mathrm{R}=0.5$ means that the competence framework ensures allocation of activities in half of the possible cases of absence of one employee,

$\mathrm{G}^{\mathrm{j}}$ - a competence framework obtained for a situation in which the $j$-th employee $G^{j}=\left(g_{k, i}^{j} \mid k=\right.$ $1 \ldots(\mathrm{m}-1) ; \mathrm{i}=1 \ldots \mathrm{n})$ is absent from his/her scheduled duty,

$\mathrm{X}^{\mathrm{j}}$ - activity assignment in the situation when the $\mathrm{j}$-th employee is absent, defined as $\mathrm{X}^{\mathrm{j}}=\left(\mathrm{x}_{\mathrm{k}, \mathrm{i}}^{\mathrm{j}} \mid \mathrm{k}=\right.$ $1 \ldots(m-1) ; i=1 \ldots n)$, where $x_{k, i}^{j} \in\{0,1\}$ : $\mathrm{x}_{\mathrm{k}, \mathrm{i}}^{\mathrm{j}}=$

$\left\{1\right.$ when activity $Z_{i}$ has been assigned to employee $P_{k}$ $\begin{cases}1 \\ 0 & \text { in the remaining cases }\end{cases}$

$c^{\mathrm{j}}-$ an auxiliary variable that specifies whether assignment $\mathrm{X}^{\mathrm{j}}$ satisfies the given constraints. The value of variable $c^{j} \in\{0,1\}$ depends on variables $c_{1, i}^{j}, c_{2, k}^{j}$, and $c_{3, k}^{j}$, which specify whether constraints (4)-(8) are satisfied.

Constraints:

1) Construction of a competence framework for situations when the $j$-th employee is absent from his scheduled duty:

$g_{k, i}^{j}=\left\{\begin{array}{cc}g_{k, i} & \text { when } k<j \\ g_{(k+1), i} & \text { when } k \geq j\end{array}\right.$

2) Activities can only be performed by employees who have appropriate competences:

$\mathrm{x}_{\mathrm{k}, \mathrm{i}}^{\mathrm{j}}=0$, when $\mathrm{g}_{\mathrm{k}, \mathrm{i}}^{\mathrm{j}}=0$, for $\mathrm{k}=1 \ldots(\mathrm{m}-1)$;

$\mathrm{i}=1 \ldots \mathrm{n} ; \mathrm{j}=1 \ldots \mathrm{m}$

3) Activities can be assigned to an employee who is free at the given time:

$$
\begin{array}{r}
\neg\left(\left(y_{\alpha}+l_{\alpha} \leq y_{\beta}\right) \vee\left(y_{\beta}+l_{\beta} \leq y_{\alpha}\right)\right) \\
\Rightarrow\left(x_{k, \alpha}^{j}+x_{k, \beta}^{j} \leq 1\right)
\end{array}
$$

for $\alpha, \beta=1 \ldots(n-1), j=1 \ldots m$

4) Activity $Z_{i}$ is assigned to exactly one employee:

$\left(\sum_{\mathrm{k}=1}^{\mathrm{m}-1} \mathrm{x}_{\mathrm{k}, \mathrm{i}}^{\mathrm{j}}=1\right) \Leftrightarrow\left(\mathrm{c}_{1, \mathrm{i}}^{\mathrm{j}}=1\right)$,

for $\mathrm{i}=1 \ldots(n-1) ; j=1 \ldots \mathrm{m}$ 


$$
\left(\sum_{\mathrm{k}=1}^{\mathrm{m}-1} \mathrm{x}_{\mathrm{k}, \mathrm{n}}^{\mathrm{j}} \geq 1\right) \Leftrightarrow\left(\mathrm{c}_{1, \mathrm{n}}^{\mathrm{j}}=1\right),
$$

for $\mathrm{j}=1 \ldots \mathrm{m}$

$\forall_{\alpha \in y_{\mathrm{n}}} \forall_{\beta \in\{1 \ldots \mathrm{n}-1\}} \exists !_{\mathrm{k} \in\{1 \ldots \mathrm{m}\}}\left(\mathrm{x}_{\mathrm{k}, \mathrm{n}}^{\mathrm{j}}=1\right) \wedge$

$\left[\left(\alpha+\mathrm{l}_{\mathrm{n}} \leq \mathrm{y}_{\beta}\right) \vee\left(\mathrm{y}_{\beta}+\mathrm{l}_{\beta} \leq \alpha\right)\right]$

5) Workload of the k-th employee should be no less than the time limit $s_{k}^{j}$ :

$\left(\sum_{\mathrm{i}=1}^{\mathrm{n}} \mathrm{x}_{\mathrm{k}, \mathrm{i}}^{\mathrm{j}} \cdot \mathrm{l}_{\mathrm{i}} \geq \mathrm{s}_{\mathrm{k}}^{\mathrm{j}}\right) \Leftrightarrow\left(\mathrm{c}_{2, \mathrm{k}}^{\mathrm{j}}=1\right)$,

for $\mathrm{k}=1 \ldots(\mathrm{m}-1) ; \mathrm{j}=1 \ldots \mathrm{m}$

6) Workload of the k-th employee should not exceed the time limit $\mathrm{z}_{\mathrm{k}}^{\mathrm{j}}$ :

$\left(\sum_{\mathrm{i}=1}^{\mathrm{n}} \mathrm{x}_{\mathrm{k}, \mathrm{i}}^{\mathrm{j}} \cdot \mathrm{l}_{\mathrm{i}} \leq \mathrm{z}_{\mathrm{k}}^{\mathrm{j}}\right) \Leftrightarrow\left(\mathrm{c}_{3, \mathrm{k}}^{\mathrm{j}}=1\right)$,

for $\mathrm{k}=1 \ldots(\mathrm{m}-1) ; \mathrm{j}=1 \ldots \mathrm{m}$

7) Robustness of the competence framework:

$$
\begin{aligned}
& \mathrm{R}=\frac{\mathrm{LP}}{\mathrm{m}} \\
& \mathrm{R} \geq \mathrm{R}^{*} \\
& \mathrm{LP}=\sum_{\mathrm{j}=1}^{\mathrm{m}} \mathrm{c}^{\mathrm{j}} \\
& \mathrm{c}^{\mathrm{j}}=\prod_{\mathrm{i}=1}^{\mathrm{n}} \mathrm{c}_{1, \mathrm{i}}^{\mathrm{j}} \prod_{\mathrm{k}=1}^{\mathrm{m}} \mathrm{c}_{2, \mathrm{k}}^{\mathrm{j}} \prod_{\mathrm{k}=1}^{\mathrm{m}} \mathrm{c}_{3, \mathrm{k}}^{\mathrm{j}}
\end{aligned}
$$

The competence framework and the activity assignment are represented in the model by decision variables $G, G^{j}$ and $X^{j}$, respectively. Activity assignment $\mathrm{X}^{\mathrm{j}}$, which satisfies constraints (1)-(12), is referred to as an admissible assignment in the situation of an absence of the j-th employee and ordering a new activity. In this context, the question to be considered is the following: Does there exist a competence framework
$G$ that can guarantee robustness $R \geq R^{*}$ in the event of an absence of a single employee and ordering a new activity?

The structure of the proposed model, which includes a set of decision variables and a set of constraints that relate those variables to one another in a natural way, allows to formulate the problem in hand as a CSP and implement it in a constraint programming environment:

$$
\mathrm{CS}=((\mathcal{V}, \mathcal{D}), \mathcal{C})
$$

where:

$\mathcal{V}=\left\{\mathrm{G}, \mathrm{G}^{1}, \ldots, \mathrm{G}^{\mathrm{m}}, \mathrm{X}^{1}, \ldots, \mathrm{X}^{\mathrm{m}}, \mathrm{R}\right\}-\mathrm{a}$ set of decision variables, which includes: competence framework $\mathrm{G}$, competence sub-frameworks $\mathrm{G}^{\mathrm{j}}$ for cases when the $\mathrm{j}$ th employee is absent, the corresponding activity assignments $X^{j}$, and robustness $\mathrm{R}$.

$\mathcal{D}$ - a finite set of decision variable domains $\left\{G, G^{1}, \ldots, G^{m}, X^{1}, \ldots, X^{m}, R\right\}$.

$\mathcal{C}-$ a set of constraints specifying the relationships between the competence framework and its robustness (constraints 1-12).

To solve CS (13), it is enough to find such values of decision variables $\mathrm{G}$ (personnel competence framework), $\mathrm{X}^{\mathrm{j}}$ (activity assignment) and $\mathrm{R}$ (robustness to absenteeism of one employee and ordering a new activity), determined by domains $\mathcal{D}$, for which all the constraints of set $\mathcal{C}$ are satisfied. In other words, what is sought is a solution that guarantees a given level $\mathrm{R}^{*}$ of robustness $\mathrm{R}$.

Table 5. Competence framework (Source: Authors' own study)

\begin{tabular}{|c|c|c|c|c|c|c|c|c|c|c|c|}
\hline $\begin{array}{l}\text { Employee } P_{i} \\
\text { (possessed competences) }\end{array}$ & $\mathrm{Z}_{1}$ & $\mathrm{Z}_{2}$ & $\mathrm{Z}_{3}$ & $\mathrm{Z}_{4}$ & $\mathrm{Z}_{5}$ & $\mathrm{Z}_{6}$ & $\mathrm{Z}_{7}$ & $\mathrm{Z}_{8}$ & $\mathrm{Z}_{9}$ & $\mathrm{Z}_{10}$ & $\mathrm{Z}_{11}$ \\
\hline $\mathrm{P}_{1}(\mathrm{~B}, \mathrm{C}, \mathrm{F})$ & 0 & 1 & 0 & 0 & 0 & 1 & 0 & 1 & 0 & 0 & 1 \\
\hline $\mathrm{P}_{2}(\mathrm{~A}, \mathrm{D})$ & 1 & 0 & 1 & 0 & 0 & 0 & 1 & 0 & 0 & 0 & 0 \\
\hline $\mathrm{P}_{3}(\mathrm{C})$ & 0 & 0 & 0 & 0 & 0 & 1 & 0 & 1 & 0 & 0 & 0 \\
\hline $\mathrm{P}_{4}(\mathrm{~F})$ & 0 & 0 & 0 & 1 & 0 & 0 & 0 & 0 & 1 & 0 & 1 \\
\hline $\mathrm{P}_{5}(\mathrm{E})$ & 0 & 0 & 0 & 0 & 1 & 0 & 0 & 0 & 0 & 1 & 0 \\
\hline $\mathrm{P}_{6}(\mathrm{~A}, \mathrm{E})$ & 1 & 0 & 0 & 0 & 1 & 0 & 1 & 0 & 0 & 1 & 0 \\
\hline $\mathrm{P}_{7}(\mathrm{~B}, \mathrm{C})$ & 0 & 1 & 0 & 0 & 0 & 1 & 0 & 1 & 0 & 0 & 0 \\
\hline $\mathrm{P}_{8}(\mathrm{~B}, \mathrm{D}, \mathrm{F})$ & 0 & 1 & 1 & 1 & 0 & 0 & 0 & 0 & 1 & 0 & 1 \\
\hline
\end{tabular}


The model was used to solve the problem of finding a competence framework robust to an absence of one employee and the arrival of a new order. The CS problem (13) was implemented in the Matlab and Gurobi environments (a Pentium i7-4770, 8 GB RAM personal computer) using data from Example 1. The experiment returned a competence framework that is shown in Table 5 (the calculation time was less than 200 seconds). A guarantee of robustness to the types of disruption being considered is obtained if employee
$\mathrm{P}_{1}$ acquires the competence needed to execute activity $\mathrm{Z}_{11}$ (the cell of Table 5 marked in green).

For example, when employee $\mathrm{P}_{8}$ is absent and a new activity $\mathrm{Z}_{11}$ (start time $\mathrm{y}_{11}=4$ ) is ordered, his/her duties (activities $Z_{3}$ and $Z_{4}$ ) are taken over by other employees $\left(\mathrm{P}_{2}\right.$ and $\left.\mathrm{P}_{4}\right)$, while activity $\mathrm{Z}_{11}$ is executed by employee $P_{1}$. The schedule is shown in Fig. 6. Any other employee can be substituted for in an analogous way to ensure timely implementation of the project.

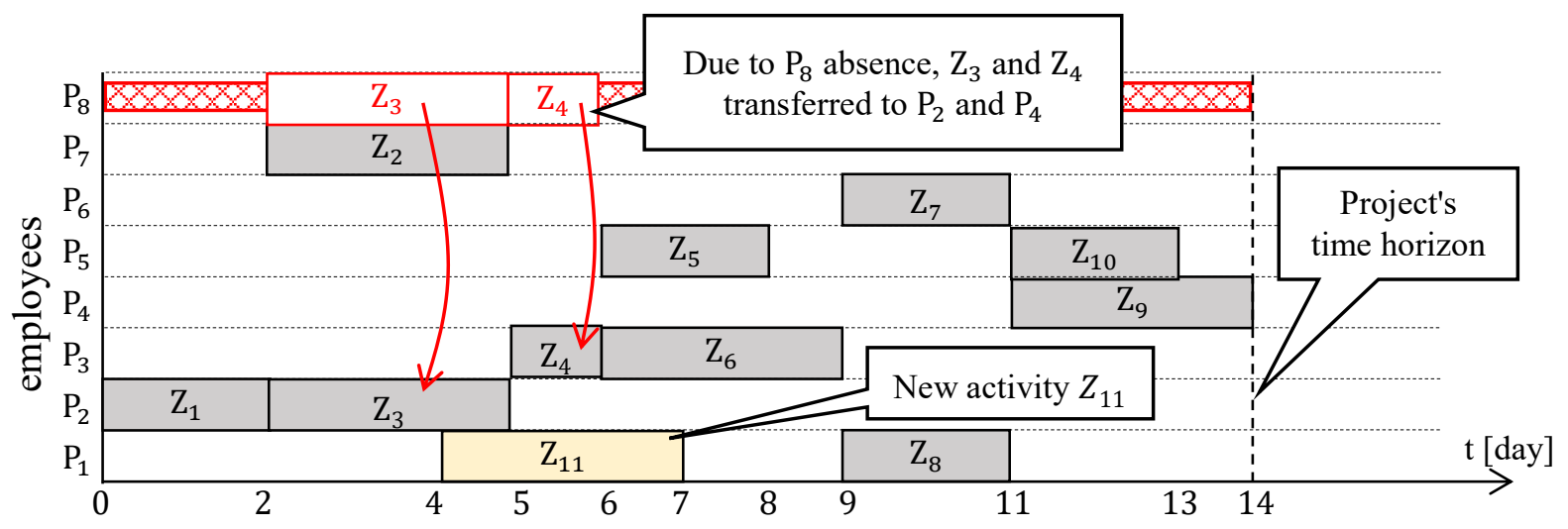

Figure 6. Employees assignment with a newly ordered activity $\mathrm{Z}_{11}$ and an accordingly modified assignment due to absence of $\mathrm{P}_{8}$ (Source: Authors' own study)

\section{Conclusions}

The problem of planning the competences of project teams requires taking into consideration the disruptions that may occur during project implementation. The proactive approach proposed in this present study involves searching for variants of competence frameworks, which allow the existing personnel to perform project activities despite disruptions. The solutions proposed so far (which took into account one type of disruption) have been extended to accommodate several types of disruption (in the case under consideration: an absence of one employee and the addition of a new activity to the ongoing project).

The proposed approach assumes that every employee takes the same amount of time to refine/acquire each competence. In practice, however, different employees may learn new skills at a different pace. This problem can be viewed as an optimization problem in which the answer to the following question is sought: Which of the alternative variants of a competence framework guarantees the fastest adjustment of the project team's competences in the event of the occurrence of the anticipated types of disruptions? This complication should be taken into account in future investigations.

In our future research, we plan to expand the present model to include issues related to the assessment of the time and costs associated with modifying a competence framework and the introduction of additional constraints regarding, among others, barriers to acquiring competences, simultaneous absences of several employees, and so on. Depending on the results we obtain, our further work will focus on building an interactive system for planning disruptionrobust competence frameworks that could be used, among others, in HR controlling. Implemented in ERP systems, this type of functionalities will enable early detection of needs and quick prototyping of alternative decisions in the area of management of staff competences.

This will allow managers to make personnel decisions online in response to employee absenteeism and/or employee turnover, legislative changes, changes in the scope of production orders, changes in customer requirements, and so on. 
6 References

[1] Antczak, A., Sypniewska, B.A., 2017. The Notion of Competence. In: Cross-Cultural Personal Selling. Palgrave Macmillan, Cham.

[2] Antosz, K., 2018. Maintenance - Identification and Analysis of the Competency Gap. Maintenance and Reliability, 20(3), pp.484-494.

[3] Appelbaum, E., 2000. Manufacturing Advantage: Why High-Performance Work Systems Pay Off. Cornell University Press.

[4] Armstrong. M., Taylor. S.. 2014. Armstrong's Handbook of Human Resource Management Practice. Kogan Page, 13 ${ }^{\text {th }}$ edition, 2014.

[5] Becker, B., Huselid, M., 2006. Strategic Human Resources Management: Where Do We Go from Here? Journal of Management, 32(6), pp.898925.

[6] Bocewicz, G., Bzdyra, K., Banaszak, Z., 2016. Robust Scheduling Subject to Multi-project Environment Constraints. In: Szewczyk R., Zieliński C., Kaliczyńska M. (eds.) Challenges in Automation, Robotics and Measurement Techniques. Advances in Intelligent Systems and Computing, Vol. 440, Springer, pp.115-126.

[7] Bocewicz, G., Wikarek, J., Sitek, P., Banaszak, Z., 2020. Robust Competence Allocation for Multi-project Scheduling. In: Świątek, J., Borzemski, L., Wilimowska, Z. (eds.) Information Systems Architecture and Technology: Proceedings of 40th Anniversary International Conference on Information Systems Architecture and Technology - ISAT 2019. Advances in Intelligent Systems and Computing, Vol. 1051, Springer, pp.16-30.

[8] Bombiak, E., 2017. Human Resources Risk as an Aspect of Human Resources Management in Turbulent Environments. In: Pînzaru F., Zbuchea A., Brătianu C., Vătămănescu E.M., Mitan A. (eds.) Shift! Major challenges of today's economy. Bucharest: Tritonic Publishing House, pp.121-132.

[9] Cheng, M.I., Dainty, A.R.J., Moore, D.R., 2003. The Differing Faces of Managerial Competency in Britain and America. Journal of Management Development, 22(6), pp.527-537.

[10] Drucker, P. 1993. Post-capitalist Society. New York: Harper Business.
[11] Gangani, N., McLean, G., Braden, R., 2006. A Competency-Based Human Resources Development Strategy. Performance Improvement Quarterly, 19(1), pp.127-139.

[12] Grabara, J.K., Kot, S., Pigoń, Ł., 2016. Recruitment Process Optimization: Chosen Findings from Practice in Poland. Journal of International Studies, 9(3), pp.217-228.

[13] Ingels, J., Maenhout, B., 2019. Optimised Buffer Allocation to Construct Stable Personnel Shift Rosters. Omega, 82, pp.102-117.

[14] Kalmi, P., Kauhanen, A., 2008. Workplace Innovations and Employee Outcomes: Evidence from Finland. Industrial Relations, 47(3), pp.430-459.

[15] Klimek, M., Łebkowski, P., 2011. Resource Allocation for Robust Project Scheduling. Bulletin of the Polish Academy of Sciences, Technical Sciences, 59(1), pp.51-55.

[16] Kupczyk, T., 2014. Competencies of Management Staff in the Knowledge-based Economy, Wroclaw: University of Business in Wroclaw.

[17] Kupczyk, T., Stor, M., 2015. Differences in Competency Management - Comparative Analysis between Polish, Spanish, and Austrian Business Practices. Journal of Intercultural Management, 7(2), pp.49-74.

[18] Kupczyk T., Stor M., 2017. Competency Management. Theory, Research and Business Practice. Wroclaw: University of Business in Wroclaw.

[19] Kuruba, M., 2019. Role Competency Matrix. A Step-By-Step Guide to an Objective Competency Management System. Singapore: Springer.

[20] Marques, G., Gourc, D., Lauras, M., 2011. Multicriteria Performance Analysis for Decision Making in Project Management. International Journal of Project Management, 29(8), pp.1057-1069.

[21] Mingus, N., 2002. Alpha Teach Yourself Project Management in 24 Hours. Penguin.

[22] Nielsen, I., Wójcik, R., Bocewicz, G., Banaszak, Z., 2014. Towards Constraint Programming Driven Methodology for Online Multi-project Planning and Control. Information Systems Architecture and Technology, Wroclaw University of Technology, pp.65-74.

[23] Oberlander, G.D., 2000. Project Management for Engineering and Construction. Boston: McGraw-Hill. 
[24] Perrenoud, P., 1997. Construire des compétences dès l'école. Pratiques et enjeux pédagogiques, Paris: ESF éditeur.

[25] Pocztowski, A., Miś, A., 2000. Managerial Competency Modeling in Terms of Human Capital in Organization. In: Shaping the Human Capital of the Company. Ed. B. Kożuch. Białystok: University of Bialystok.

[26] Romainville, M., 1996. L'irrésistible ascension du terme compétence en éducation, Enjeux, No. $37 / 38$.

[27] Sampson, D., Fytros, D., 2008. Competence Models in Technology-enhanced Competence-based Learning. In: Adelsberger, H.H., Kinshuk, Pawlowski J.M., Sampson D. (Eds.), Handbook on information Technologies for Education and Training. Heidelberg: Springer-Verlag, pp.155177.

[28] Sitek, P., 2014. A Hybrid CP/MP Approach to Supply Chain Modelling, Pptimization and Analysis. Proceedings of the 2014 Federated Conference on Computer Science and Information Systems. Series: ACSIS-Annals of Computer Science and Information Systems, Vol. 2, pp.13451352.

[29] Sitek, T., Ziółkowski, A., 2014. Project-FactorDecision - Decisive Factors in It Projects and
Their Impact on Its Success. Information Systems in Management, 3(2), pp.145-155.

[30] Stor, M., 2014. Reconceptualizing Strategic International Human Resources Management in Pursuing Sustainable Competitive Advantage of MNCs. Human Resource Management, 6(10), pp.11-31.

[31] Szwarc, E., Bocewicz, G., Bach-Dąbrowska, I., 2019a. Planning of Teacher Staff Competence Framework Robust to Unexpected Personnel Absence. Manufacturing Modelling, Management and Control (MIM 2019), Berlin (in print).

[32] Szwarc, E., Bocewicz, G., Banaszak, Z., Wikarek, J., 2019b. Competence Allocation Planning Robust to Unexpected Staff Absenteeism. Maintenance and Reliability, 21(3), pp.440-450. doi: 10.17531/ein.2019.3.10.

[33] Teodorescu, T., 2006. Competence Versus Competency. What Is the Difference? Performance Improvement, 45(10), pp.27-30.

[34] Vaagen, H., Kaut, M., Wallace, S.W., 2017. The Impact of Design Uncertainty in Engineerto-Order Project Planning. European Journal of Operational Research, 261(3), pp.1098-1109.

[35] Zhu, G., Bard, J.F., Yu, G., 2005. Disruption Management for Resource-Constrained Project Scheduling. Journal of Operational Research Society, 56, pp.365-381. 